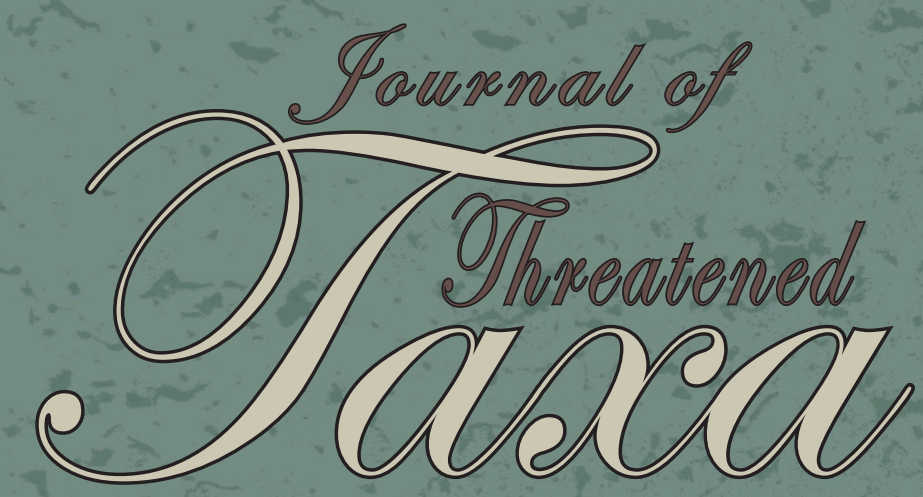

Building evidence for conservation globally
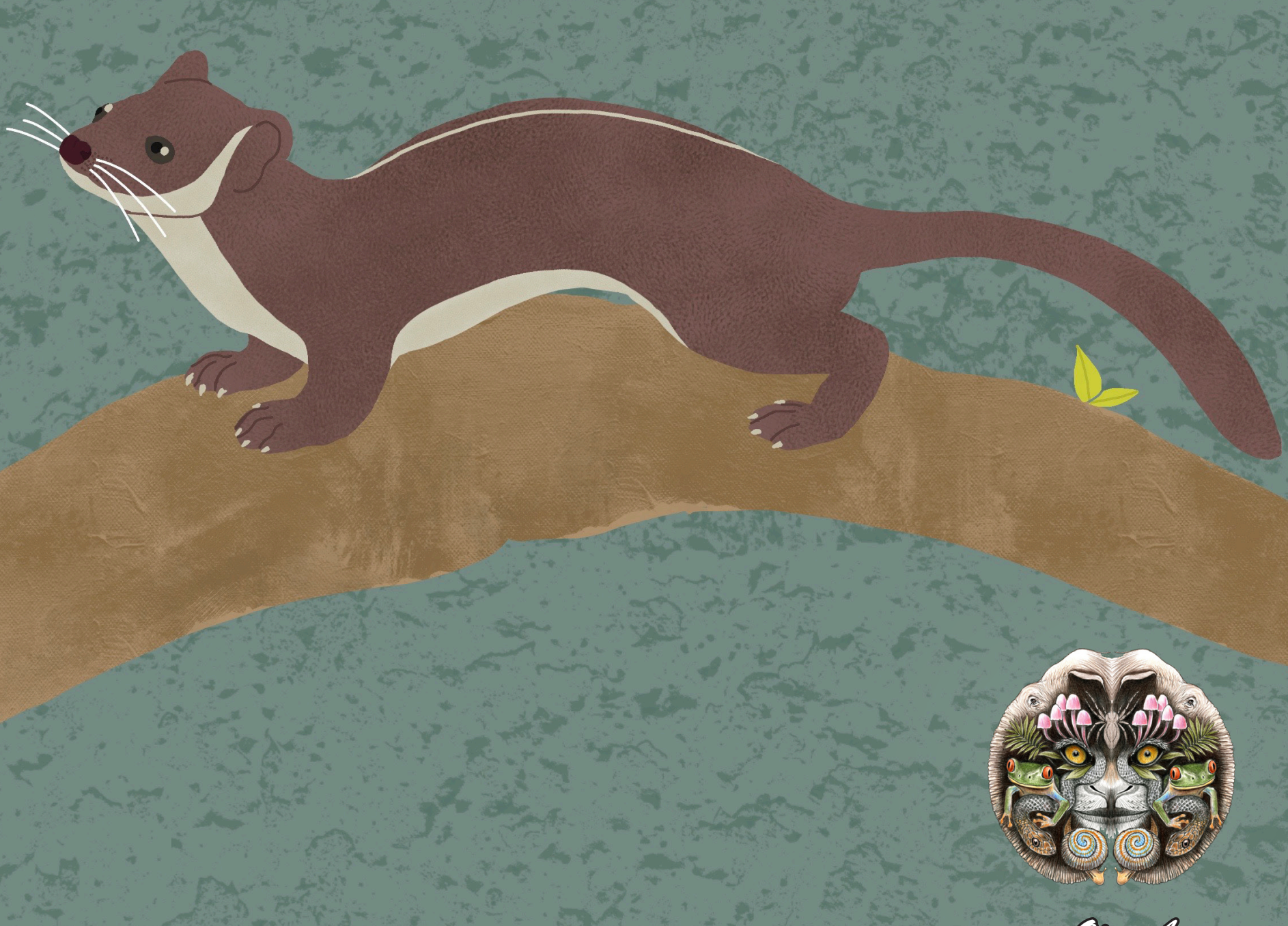

Qpecosecess

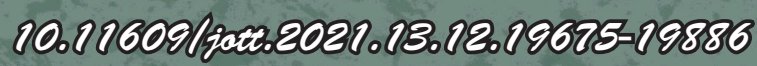
cocosurthreatecredtassararg

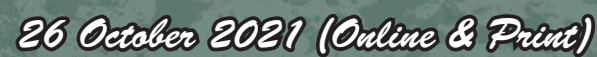

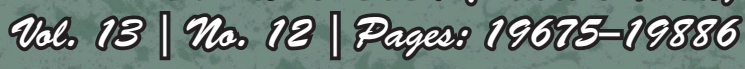




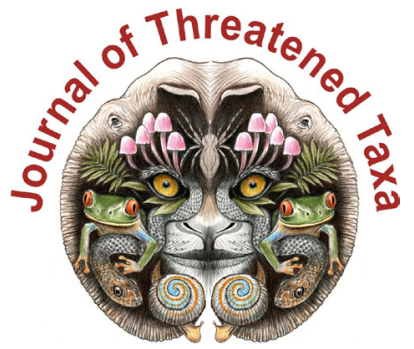

ISSN 0974-7907 (Online); ISSN $0974-7893$ (Print)

Publisher

Host

Wildlife Information Liaison Development Society

www.wild.zooreach.org

Zoo Outreach Organization www.zooreach.org

No. 12, Thiruvannamalai Nagar, Saravanampatti - Kalapatti Road, Saravanampatti, Coimbatore, Tamil Nadu 641035, India

Ph: +91 9385339863 | www.threatenedtaxa.org

Email: sanjay@threatenedtaxa.org

EDITORS

\section{Founder \& Chief Editor}

Dr. Sanjay Molur

Wildlife Information Liaison Development (WILD) Society \& Zoo Outreach Organization (ZOO)

12 Thiruvannamalai Nagar, Saravanampatti, Coimbatore, Tamil Nadu 641035, India

\section{Deputy Chief Edito}

Dr. Neelesh Dahanukar

Noida, Uttar Pradesh, India

\section{Managing Editor}

Mr. B. Ravichandran, WILD/ZOO, Coimbatore, India

\section{Associate Editors}

Dr. Mandar Paingankar, Government Science College Gadchiroli, Maharashtra 442605, India Dr. Ulrike Streicher, Wildlife Veterinarian, Eugene, Oregon, USA

Ms. Priyanka Iyer, ZOO/WILD, Coimbatore, Tamil Nadu 641035, India

Dr. B. A. Daniel, $200 /$ WIID, Coimbatore, Tamil Nadu 641035, India

\section{Editorial Board}

Dr. Russel Mittermeie

Executive Vice Chair, Conservation International, Arlington, Virginia 22202, USA

\section{Prof. Mewa Singh Ph.D., FASc, FNA, FNASc, FNAPsy}

Ramanna Fellow and Life-Long Distinguished Professor, Biopsychology Laboratory, and Institute of Excellence, University of Mysore, Mysuru, Karnataka 570006, India; Honorary Professor, Jawaharlal Nehru Centre for Advanced Scientific Research, Bangalore; and Adjunct Professor, National Institute of Advanced Studies, Bangalore

\section{Stephen D. Nash}

Scientific Illustrator, Conservation International, Dept. of Anatomical Sciences, Health Sciences Center, T-8, Room 045, Stony Brook University, Stony Brook, NY 11794-8081, USA

\section{Dr. Fred Pluthero}

Toronto, Canada

\section{Dr. Priya Davidar}

Sigur Nature Trust, Chadapatti, Mavinhalla PO, Nilgiris, Tamil Nadu 643223, India

\section{Dr. Martin Fisher}

Senior Associate Professor, Battcock Centre for Experimental Astrophysics, Cavendish

Laboratory, JJ Thomson Avenue, Cambridge CB3 OHE, UK

\section{Dr. John Fellowes}

Honorary Assistant Professor, The Kadoorie Institute, 8/F, T.T. Tsui Building, The University of Hong Kong, Pokfulam Road, Hong Kong

\section{Prof. Dr. Mirco Solé}

Universidade Estadual de Santa Cruz, Departamento de Ciências Biológicas, Vice-coordenado do Programa de Pós-Graduação em Zoologia, Rodovia Ilhéus/Itabuna, Km 16 (45662-000)

Salobrinho, Ilhéus - Bahia - Brasil

\section{Dr. Rajeev Raghavan}

Professor of Taxonomy, Kerala University of Fisheries \& Ocean Studies, Kochi, Kerala, India

\section{English Editors}

Mrs. Mira Bhojwani, Pune, India

Dr. Fred Pluthero, Toronto, Canad

Mr. P. Ilangovan, Chennai, India

Web Maintenance

Mrs. Latha G. Ravikumar, ZOO/WILD, Coimbatore, India

\section{Typesetting}

Mr. Arul Jagadish, ZOO, Coimbatore, India

Mrs. Radhika, ZOO, Coimbatore, India

Mrs. Geetha, ZOO, Coimbatore India

\section{Fundraising/Communications}

Mrs. Payal B. Molur, Coimbatore, India

Subject Editors 2018-2020

Fungi

Dr. B. Shivaraju, Bengaluru, Karnataka, India

Dr. R.K. Verma, Tropical Forest Research Institute, Jabalpur, India

Dr. Vatsavaya S. Raju, Kakatiay University, Warangal, Andhra Pradesh, India

Dr. M. Krishnappa, Jnana Sahyadri, Kuvempu University, Shimoga, Karnataka, India

Dr. K.R. Sridhar, Mangalore University, Mangalagangotri, Mangalore, Karnataka, India

Dr. Gunjan Biswas, Vidyasagar University, Midnapore, West Bengal, India

Plants

Dr. G.P. Sinha, Botanical Survey of India, Allahabad, India

Dr. N.P. Balakrishnan, Ret. Joint Director, BSI, Coimbatore, India

Dr. Shonil Bhagwat, Open University and University of Oxford, UK

Prof. D.J. Bhat, Retd. Professor, Goa University, Goa, India

Dr. Ferdinando Boero, Università del Salento, Lecce, Italy

Dr. Dale R. Calder, Royal Ontaro Museum, Toronto, Ontario, Canada

Dr. Cleofas Cervancia, Univ. of Philippines Los Baños College Laguna, Philippines

Dr. F.B. Vincent Florens, University of Mauritius, Mauritius

Dr. Merlin Franco, Curtin University, Malaysia

Dr. V. Irudayaraj, St. Xavier's College, Palayamkottai, Tamil Nadu, India

Dr. B.S. Kholia, Botanical Survey of India, Gangtok, Sikkim, India

Dr. Pankaj Kumar, Kadoorie Farm and Botanic Garden Corporation, Hong Kong S.A.R., China

Dr. V. Sampath Kumar, Botanical Survey of India, Howrah, West Bengal, India

Dr. A.J. Solomon Raju, Andhra University, Visakhapatnam, India

Dr. Vijayasankar Raman, University of Mississippi, USA

Dr. B. Ravi Prasad Rao, Sri Krishnadevaraya University, Anantpur, India

Dr. K. Ravikumar, FRLHT, Bengaluru, Karnataka, India

Dr. Aparna Watve, Pune, Maharashtra, India

Dr. Qiang Liu, Xishuangbanna Tropical Botanical Garden, Yunnan, China

Dr. Noor Azhar Mohamed Shazili, Universiti Malaysia Terengganu, Kuala Terengganu, Malaysia Dr. M.K. Vasudeva Rao, Shiv Ranjani Housing Society, Pune, Maharashtra, India

Prof. A.J. Solomon Raju, Andhra University, Visakhapatnam, India

Dr. Mandar Datar, Agharkar Research Institute, Pune, Maharashtra, India

Dr. M.K. Janarthanam, Goa University, Goa, India

Dr. K. Karthigeyan, Botanical Survey of India, India

Dr. Errol Vela, University of Montpellier, Montpellier, France

Dr. P. Lakshminarasimhan, Botanical Survey of India, Howrah, India

Dr. Larry R. Noblick, Montgomery Botanical Center, Miami, USA

Dr. K. Haridasan, Pallavur, Palakkad District, Kerala, India

Dr. Analinda Manila-Fajard, University of the Philippines Los Banos, Laguna, Philippines

Dr. P.A. Sinu, Central University of Kerala, Kasaragod, Kerala, India

Dr. Afroz Alam, Banasthali Vidyapith (accredited A grade by NAAC), Rajasthan, India

Dr. K.P. Rajesh, Zamorin's Guruvayurappan College, GA College PO, Kozhikode, Kerala, India

Dr. David E. Boufford, Harvard University Herbaria, Cambridge, MA 02138-2020, USA

Dr. Ritesh Kumar Choudhary, Agharkar Research Institute, Pune, Maharashtra, India

Dr. Navendu Page, Wildlife Institute of India, Chandrabani, Dehradun, Uttarakhand, India

Invertebrates

Dr. R.K. Avasthi, Rohtak University, Haryana, India

Dr. D.B. Bastawade, Maharashtra, India

Dr. Partha Pratim Bhattacharjee, Tripura University, Suryamaninagar, India

Dr. Kailash Chandra, Zoological Survey of India, Jabalpur, Madhya Pradesh, India

Dr. Ansie Dippenaar-Schoeman, University of Pretoria, Queenswood, South Africa

Dr. Rory Dow, National Museum of natural History Naturalis, The Netherlands

Dr. Brian Fisher, California Academy of Sciences, USA

Dr. Richard Gallon, llandudno, North Wales, LL30 1UP

Dr. Hemant V. Ghate, Modern College, Pune, India

Dr. M. Monwar Hossain, Jahangirnagar University, Dhaka, Bangladesh

Mr. Jatishwor Singh Irungbam, Biology Centre CAS, Branišovská, Czech Republic.

Dr. lan J. Kitching, Natural History Museum, Cromwell Road, UK

Dr. George Mathew, Kerala Forest Research Institute, Peechi, India

Dr. John Noyes, Natural History Museum, London, UK

For Focus, Scope, Aims, and Policies, visit https://threatenedtaxa.org/index.php/JoTT/aims_scope
For Article Submission Guidelines, visit https://threatenedtaxa.org/index.php/JoTT/about/submissions
For Policies against Scientific Misconduct, visit https://threatenedtaxa.org/index.php/JoTT/policies_various

continued on the back inside cover 


\title{
The genus Catapiestus Perty, 1831 (Coleoptera: Tenebrionidae: Cnodalonini) from Arunachal Pradesh with one new record to India
}

\author{
V.D. Hegde ${ }^{1}$ (D) \& Sarita Yadav ${ }^{2}$ (D) \\ ${ }^{1,2}$ North Eastern Regional Centre, Zoological Survey of India, Risa Colony, Shillong, Meghalaya 793003, India. \\ ${ }^{1}$ hegde67@yahoo.co.in (corresponding author), 2 saritayadavzsi18@gmail.com
}

The genus Catapiestus Perty, 1831 belongs to the tribe Cnodalonini (Tenebrionidae: Stenochiinae), and has at present 12 species in the Oriental and Palaearctic regions, including four species already reported from various parts of India, viz, Catapiestus bourgoini Pic, 1912 from Malabar- Mahe, Catapiestus piceiventris Fairmaire, 1893 from Andaman Island, Catapiestus indicus Fairmaire, 1896 from Kanara \& Sikkim, and Catapiestus subrufescens Pic, 1911 from Dudhwa National Park, Uttar Pradesh (Lang \& Ren 2009; Hegde \& Lal 2014). The species of this genus have quite uniform characters - strongly flattened body form and coloration and scarce or no apparent external sexual dimorphism (Lang \& Ren 2009). Morphological differentiation of the species mainly depends on features of the pronotum and number of teeth or denticles of profemora (Lang \& Ren 2009). In the check-list of Tenebrionidae of Arunachal Pradesh, Hegde (2019) reported only one species $C$. indicus. Examination of the collection at North Eastern Regional Centre (NERC), Zoological Survey of India (ZSI), Shillong, revealed that there are three species $C$. subrufescens, $C$. piceiventris, and $C$. rugipennis collected from Arunachal Pradesh in 1982. These three species are new records for Arunachal Pradesh while $C$. rugipennis (originally described from Japan) is the first

\section{report from India.}

Material and Methods: The specimens were in the unidentified collection of NERC, ZSI, Shillong, Meghalaya, which were identified up to species level by their morphological characters following Lang \& Ren (2009). The identified specimens were registered and deposited in the national zoological collections of ZSI, Shillong. The images were taken with binocular microscope using Leica DFC 450 camera.

\section{Genus Catapiestus Perty, 1831}

Diagnostic features: The genus Catapiestus was proposed by Perty (1831) with C. Piceus Perty, 1831 as type species. Subsequently, one species was described by Guèrin-Mèneville (1841), four species by Fairmaire (1888, 1893, 1896), three species by Pic (1911, 1912), and one species by Chûjô (1984).

Body elongate, parallel sided, strongly depressed, Body dark brown, with dense punctures. Head broad, space between eyes broad, neck slender, and nearly cylindrical. Distal six segments of antenna dilated. Maxillary palpus with apical segments strongly securiforme. The lateral margins of pronotum with serrations, and the middle and/or lateral with depression. Elytra with distinct punctures and striae. record to India. Journal of Threatened Taxa 13(12): 19867-19869. https://doi.org/10.11609/jott.6463.13.12.19867-19869

Copyright: ( ) Hegde \& Yadav 2021. Creative Commons Attribution 4.0 International License. JoTT allows unrestricted use, reproduction, and distribution of this article in any medium by providing adequate credit to the author(s) and the source of publication.

Funding: Based on the Annual Programme of Research, Zoological Survey of India under the Ministry of Environment, Forest and Climate Change, Govt. of India. 
Legs slender, femur with or without tooth, tibial spurs extremely underdeveloped, tarsi with hairs. There is no distinct sexual dimorphism.

\section{Catapiestus subrufescens Pic, 1911}

1911. Catapiestus subrufescens Pic, L'Échange, Revue Linnéenne 27: 134.

Material examined: Reg. No. I/COL/NERC- 142, 24.viii.1982, 1 specimen (sex undiagnosed), Derok Forest, Tirap Dist., Arunachal Pradesh, India, coll. C. Radhakrishnan.

Diagnostic characters: Body length: $16 \mathrm{~mm}$, body blackish-brown, strongly depressed and with dense punctures. Pronotum lateral margins curved with small radius, with more acute serrations than upper, front, corner acute, hinder corner rounded, elytra punctate striate, distal six segments of the antenna dilated (Image $1)$.

Distribution: India (Uttar Pradesh and Arunachal Pradesh (New Record)), China, Taiwan (Type locality, Pic 1911; Lang \& Ren 2009).

\section{Catapiestus piceiventris Fairmaire, 1893}

1893. Catapiestus piceiventris Fairmaire, Notes from the Leyden Museum, 15: 29.

Material examined: Reg. No. I/COL/NERC- 143, 24.viii.1982, 1 specimen (sex undiagnosed), Derak Forest, Tirap Dist., Arunachal Pradesh, India, coll. C. Radhakrishnan.

Diagnostic characters: Body length: $14 \mathrm{~mm}$, body blackish-brown, strongly depressed and with dense punctures. Pronotum almost flat, middle with shallow depression with dense puncture (Image 2).

Distribution: India (Andaman Island (Type locality: Fairmaire 1893; Lang \& Ren 2009) and Arunachal Pradesh (New Record)).

\section{Catapiestus rugipennis Chûjô, 1984}

1984. Catapiestus rugipennis Chûjô, ESAKIA, 22: 1.

Material examined: Reg. No. I/COL/NERC-144, 24.viii.1982, 1 specimen (sex undiagnosed), Derok forest, Tirap Dist., Arunachal Pradesh, coll. C. Radhakrishnan.

Diagnostic characters: Body length: $14 \mathrm{~mm}$. Body uniformly shining dark brown, strongly depressed. Elytra punctuate striate with sparse, small punctures, punctures laterally connected with fine reticulate. Profemur with one small tooth on front ridge (Image 3 ).

Distribution: India (Arunachal Pradesh (new India record)), Japan (Amami-Oshima Island and Okinawa Honto Island (Type locality: Chûjô, 1984; Lang \& Ren 2009)).

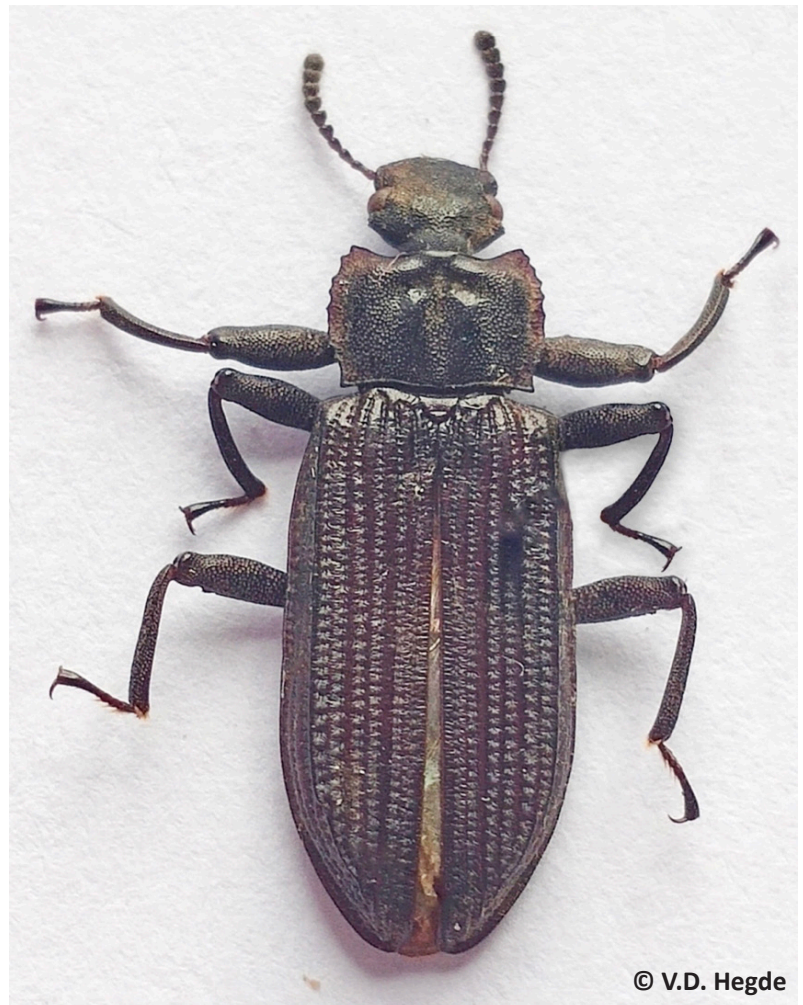

Image 1. Catapiestus subrufescens (Reg. No. I/COL/NERC-142).

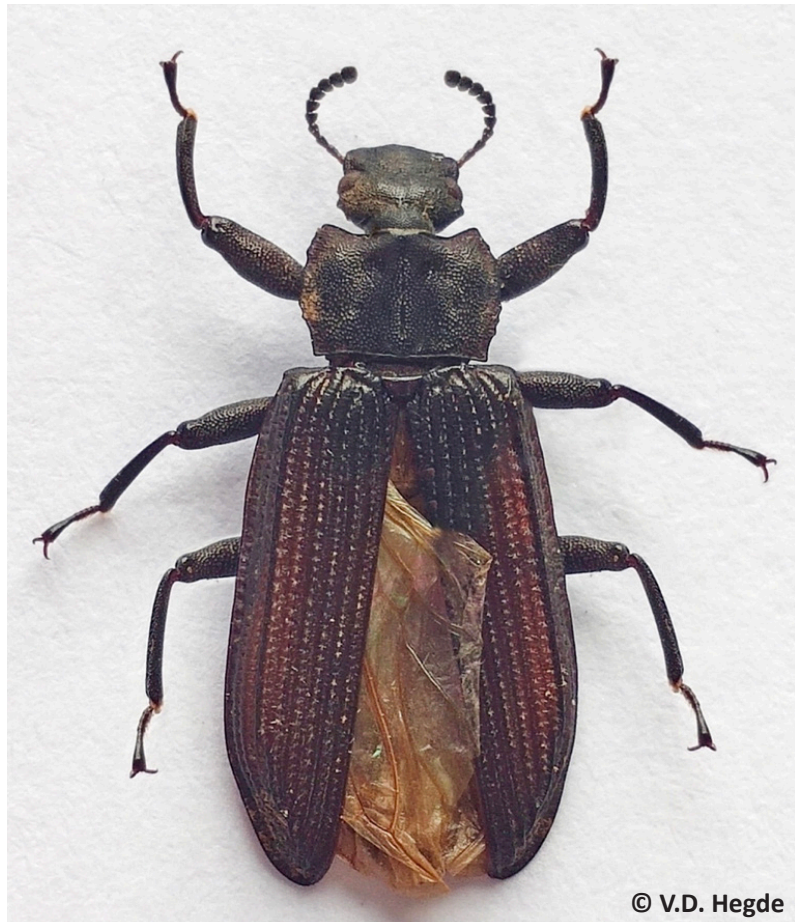

Image 2. Catapiestus piceiventris (Reg. No. I/COL/NERC- 143). 


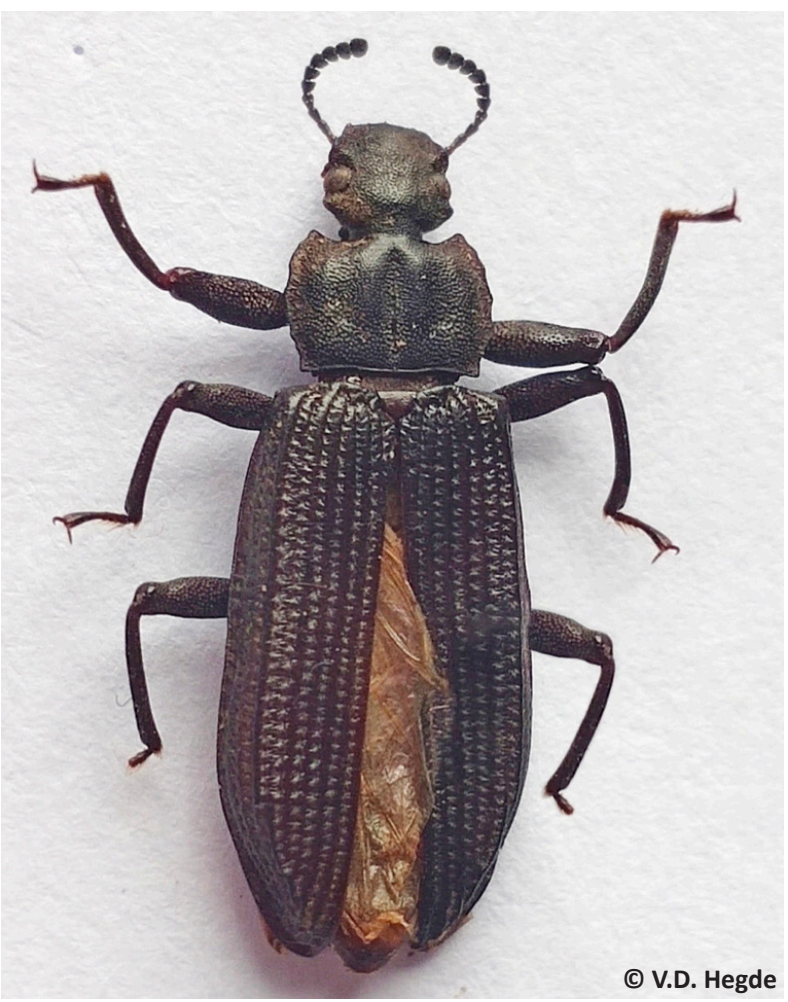

Image 3. Catapiestus rugipennis (Reg. No. I/COL/NERC-144).

Discussion: The species of the genus Catapiestus are mainly distributed in the subtropical forests of southeastern Asia (Hegde \& Lal 2014). Till now only four species of Catapiestus are reported from India. With the report of $C$. rugipennis in this paper, the total number of known Catapiestus species from India now stands at five.

From Arunachal Pradesh, only C. indicus was previously reported (Hegde 2019). The report of C. subrufescens, C. Piceiventris, and C .rugipennis constitutes the first record from the state, thus raising the total number of Catapiestus to four species for Arunachal Pradesh.

The known diversity of Catapiestus populations in India is disjunct and largely known from the northeastern states of Arunachal Pradesh and Sikkim, along with Uttar Pradesh and the southern state of Karnataka and Puducherry from the Malabar Coast as well as Andaman Islands (Fairmaire 1893, 1896; Pic 1912; Hegde \& Lal 2014; Hegde 2019). The current
A key to the India Catapiestus fauna is provided for the benefit of easy taxonomic identification

1. The middle longitudinal groove on pronotum distinct ............ 2 The middle longitudinal groove on pronotum indistinct .......

2. Transverse groove on the anterior pronotum absent .......... 3 Transverse groove on the anterior pronotum present ..... C. subrufescens

3. Pronotum without puncture posteriorly ............................ 4 Pronotum with puncture posteriorly ..................... C. bourgoini

4. Anterior pronotum lifted C. rugipennis Anterior pronotum depressed C. piceiventris

report of this group from Arunachal Pradesh (in Tirap) is from the lower altitudinal areas which suggest that the other hill states of northeastern India might harbour yet unknown populations of this genus, as the entire area comes under the confluence of the eastern Himalaya and the Indo-Burma biodiversity hotspots. As the hilly states of northeastern India are still largely inaccessible and poorly surveyed, there is a dearth of documentation of insect fauna from the region, which is probably the reason why the known diversity of Catapiestus is still low.

\section{References}

Chûjô, M.T. (1984). Tenebrionidae of the Nansei Islands IX (Coleoptera) Esakia 22: 1-4.

Fairmaire, L. (1888). Descriptions de Colèoptères de I'Indo-Chine Annales de la Sociètè Entomologique de France (6)8: 333-378.

Fairmaire, L. (1893). Colèoptères nouveaux des Indes Orientales, de la famille des Scarabaeidae, Rhipidoceridae, Tenebrionidae et Oedemeridae. Notes from the Leyden Museum 15: 17-64.

Fairmaire, L. (1896). Hètèromères de I'Inde recueillis par $M$. Andrewes. Annales de la Sociètè Entomologique de Belgique 40: 6-62.

Hegde, V.D. (2019). Checklist of darkling beetles (Coleoptera: Tenebrionidae) of Arunachal Pradesh, India. Records of the Zoological Survey of India 119(1): 69-77.

Hegde, V.D. \& B. Lal (2014). New record of Catapiestus subrufescens Pic, 1911 (Coleoptera: Tenebrionidae: Cnodalonini) from India. Bugs $R$ All 21: 4-5.

Lang, J.T. \& G.D. Ren (2009). A review of the genus Catapiestus Perty, 1831 (Coleoptera: Tenebrionidae: Cnodalonini) with descriptions of two new species from China, Caucasian Entomological Bulletin 5(2): 195-199.

Pic, M. (1911). Coleopteres exotiques nouveaux oupeuconnus (Suite). L'Ëchange. Revue Linnéenne 27: 132-134, 138

Pic, M. (1912). Descriptions déspeces et varieties diverses. Melanges Exotico-Entomologiques 3: 6-20. 

Dr. Albert G. Orr, Griffith University, Nathan, Australia

Dr. Sameer Padhye, Katholieke Universiteit Leuven, Belgium

Dr. Nancy van der Poorten, Toronto, Canada

Dr. Kareen Schnabel, NIWA, Wellington, New Zealand

Dr. R.M. Sharma, (Retd.) Scientist, Zoological Survey of India, Pune, India

Dr. Manju Siliwal, WILD, Coimbatore, Tamil Nadu, India

Dr. G.P. Sinha, Botanical Survey of India, Allahabad, India

Dr. K.A. Subramanian, Zoological Survey of India, New Alipore, Kolkata, India

Dr. P.M. Sureshan, Zoological Survey of India, Kozhikode, Kerala, India

Dr. R. Varatharajan, Manipur University, Imphal, Manipur, India

Dr. Eduard Vives, Museu de Ciències Naturals de Barcelona, Terrassa, Spain

Dr. James Young, Hong Kong Lepidopterists' Society, Hong Kong

Dr. R. Sundararaj, Institute of Wood Science \& Technology, Bengaluru, India

Dr. M. Nithyanandan, Environmental Department, La Ala Al Kuwait Real Estate. Co. K.S.C., Kuwait

Dr. Himender Bharti, Punjabi University, Punjab, India

Mr. Purnendu Roy, London, UK

Dr. Saito Motoki, The Butterfly Society of Japan, Tokyo, Japan

Dr. Sanjay Sondhi, TITLI TRUST, Kalpavriksh, Dehradun, India

Dr. Nguyen Thi Phuong Lien, Vietnam Academy of Science and Technology, Hanoi, Vietnam

Dr. Nitin Kulkarni, Tropical Research Institute, Jabalpur, India

Dr. Robin Wen Jiang Ngiam, National Parks Board, Singapore

Dr. Lional Monod, Natural History Museum of Geneva, Genève, Switzerland.

Dr. Asheesh Shivam, Nehru Gram Bharti University, Allahabad, India

Dr. Rosana Moreira da Rocha, Universidade Federal do Paraná, Curitiba, Brasil

Dr. Kurt R. Arnold, North Dakota State University, Saxony, Germany

Dr. James M. Carpenter, American Museum of Natural History, New York, USA

Dr. David M. Claborn, Missouri State University, Springfield, USA

Dr. Kareen Schnabel, Marine Biologist, Wellington, New Zealand

Dr. Amazonas Chagas Júnior, Universidade Federal de Mato Grosso, Cuiabá, Brasil

Mr. Monsoon Jyoti Gogoi, Assam University, Silchar, Assam, India

Dr. Heo Chong Chin, Universiti Teknologi MARA (UiTM), Selangor, Malaysia

Dr. R.J. Shiel, University of Adelaide, SA 5005, Australia

Dr. Siddharth Kulkarni, The George Washington University, Washington, USA

Dr. Priyadarsanan Dharma Rajan, ATREE, Bengaluru, India

Dr. Phil Alderslade, CSIRO Marine And Atmospheric Research, Hobart, Australia

Dr. John E.N. Veron, Coral Reef Research, Townsville, Australia

Dr. Daniel Whitmore, State Museum of Natural History Stuttgart, Rosenstein, Germany.

Dr. Yu-Feng Hsu, National Taiwan Normal University, Taipei City, Taiwan

Dr. Keith V. Wolfe, Antioch, California, USA

Dr. Siddharth Kulkarni, The Hormiga Lab, The George Washington University, Washington,

D.C., USA

Dr. Tomas Ditrich, Faculty of Education, University of South Bohemia in Ceske

Budejovice, Czech Republic

Dr. Mihaly Foldvari, Natural History Museum, University of Oslo, Norway

Dr. V.P. Uniyal, Wildlife Institute of India, Dehradun, Uttarakhand 248001, India

Dr. John T.D. Caleb, Zoological Survey of India, Kolkata, West Bengal, India

Dr. Priyadarsanan Dharma Rajan, Ashoka Trust for Research in Ecology and the Environment (ATREE), Royal Enclave, Bangalore, Karnataka, India

\section{Fishes}

Dr. Neelesh Dahanukar, IISER, Pune, Maharashtra, India

Dr. Topiltzin Contreras MacBeath, Universidad Autónoma del estado de Morelos, México

Dr. Heok Hee Ng, National University of Singapore, Science Drive, Singapore

Dr. Rajeev Raghavan, St. Albert's College, Kochi, Kerala, India

Dr. Robert D. Sluka, Chiltern Gateway Project, A Rocha UK, Southall, Middlesex, UK

Dr. E. Vivekanandan, Central Marine Fisheries Research Institute, Chennai, India

Dr. Davor Zanella, University of Zagreb, Zagreb, Croatia

Dr. A. Biju Kumar, University of Kerala, Thiruvananthapuram, Kerala, India

Dr. Akhilesh K.V., ICAR-Central Marine Fisheries Research Institute, Mumbai Research

Centre, Mumbai, Maharashtra, India

Dr. J.A. Johnson, Wildlife Institute of India, Dehradun, Uttarakhand, India

\section{Amphibians}

Dr. Sushil K. Dutta, Indian Institute of Science, Bengaluru, Karnataka, India

Dr. Annemarie Ohler, Muséum national d'Histoire naturelle, Paris, France

\section{Reptiles}

Dr. Gernot Vogel, Heidelberg, Germany

Dr. Raju Vyas, Vadodara, Gujarat, India

Dr. Pritpal S. Soorae, Environment Agency, Abu Dubai, UAE.

Prof. Dr. Wayne J. Fuller, Near East University, Mersin, Turkey

Prof. Chandrashekher U. Rivonker, Goa University, Taleigao Plateau, Goa. India

Dr. S.R. Ganesh, Chennai Snake Park, Chennai, Tamil Nadu, India

Dr. Himansu Sekhar Das, Terrestrial \& Marine Biodiversity, Abu Dhabi, UAE
Birds

Dr. Hem Sagar Baral, Charles Sturt University, NSW Australia

Dr. Chris Bowden, Royal Society for the Protection of Birds, Sandy, UK

Dr. Priya Davidar, Pondicherry University, Kalapet, Puducherry, India

Dr. J.W. Duckworth, IUCN SSC, Bath, UK

Dr. Rajah Jayapal, SACON, Coimbatore, Tamil Nadu, India

Dr. Rajiv S. Kalsi, M.L.N. College, Yamuna Nagar, Haryana, India

Dr. V. Santharam, Rishi Valley Education Centre, Chittoor Dt., Andhra Pradesh, India

Dr. S. Balachandran, Bombay Natural History Society, Mumbai, India

Mr. J. Praveen, Bengaluru, India

Dr. C. Srinivasulu, Osmania University, Hyderabad, India

Dr. K.S. Gopi Sundar, International Crane Foundation, Baraboo, USA

Dr. Gombobaatar Sundev, Professor of Ornithology, Ulaanbaatar, Mongolia

Prof. Reuven Yosef, International Birding \& Research Centre, Eilat, Israel

Dr. Taej Mundkur, Wetlands International, Wageningen, The Netherlands

Dr. Carol Inskipp, Bishop Auckland Co., Durham, UK

Dr. Tim Inskipp, Bishop Auckland Co, Durham, UK

Dr. V. Gokula, National College, Tiruchirappalli, Tamil Nadu, India

Dr. Arkady Lelej, Russian Academy of Sciences, Vladivostok, Russia

Dr. Simon Dowell, Science Director, Chester Zoo, UK

Dr. Mário Gabriel Santiago dos Santos, Universidade de Trás-os-Montes e Alto Douro,

Quinta de Prados, Vila Real, Portugal

Dr. Grant Connette, Smithsonian Institution, Royal, VA, USA

Dr. M. Zafar-ul Islam, Prince Saud Al Faisal Wildlife Research Center, Taif, Saudi Arabia

Mammals

Dr. Giovanni Amori, CNR - Institute of Ecosystem Studies, Rome, Italy

Dr. Anwaruddin Chowdhury, Guwahati, India

Dr. David Mallon, Zoological Society of London, UK

Dr. Shomita Mukherjee, SACON, Coimbatore, Tamil Nadu, India

Dr. Angie Appel, Wild Cat Network, Germany

Dr. P.O. Nameer, Kerala Agricultural University, Thrissur, Kerala, India

Dr. Ian Redmond, UNEP Convention on Migratory Species, Lansdown, UK

Dr. Heidi S. Riddle, Riddle's Elephant and Wildlife Sanctuary, Arkansas, USA

Dr. Karin Schwartz, George Mason University, Fairfax, Virginia.

Dr. Lala A.K. Singh, Bhubaneswar, Orissa, India

Dr. Mewa Singh, Mysore University, Mysore, India

Dr. Paul Racey, University of Exeter, Devon, UK

Dr. Honnavalli N. Kumara, SACON, Anaikatty P.O., Coimbatore, Tamil Nadu, India

Dr. Nishith Dharaiya, HNG University, Patan, Gujarat, India

Dr. Spartaco Gippoliti, Socio Onorario Società Italiana per la Storia della Fauna "Giuseppe

Altobello", Rome, Italy

Dr. Justus Joshua, Green Future Foundation, Tiruchirapalli, Tamil Nadu, India

Dr. H. Raghuram, The American College, Madurai, Tamil Nadu, India

Dr. Paul Bates, Harison Institute, Kent, UK

Dr. Jim Sanderson, Small Wild Cat Conservation Foundation, Hartford, USA

Dr. Dan Challender, University of Kent, Canterbury, UK

Dr. David Mallon, Manchester Metropolitan University, Derbyshire, UK

Dr. Brian L. Cypher, California State University-Stanislaus, Bakersfield, CA

Dr. S.S. Talmale, Zoological Survey of India, Pune, Maharashtra, India

Prof. Karan Bahadur Shah, Budhanilakantha Municipality, Kathmandu, Nepal

Dr. Susan Cheyne, Borneo Nature Foundation International, Palangkaraja, Indonesia

Dr. Hemanta Kafley, Wildlife Sciences, Tarleton State University, Texas, USA

\section{Other Disciplines}

Dr. Aniruddha Belsare, Columbia MO 65203, USA (Veterinary)

Dr. Mandar S. Paingankar, University of Pune, Pune, Maharashtra, India (Molecular)

Dr. Jack Tordoff, Critical Ecosystem Partnership Fund, Arlington, USA (Communities)

Dr. Ulrike Streicher, University of Oregon, Eugene, USA (Veterinary)

Dr. Hari Balasubramanian, EcoAdvisors, Nova Scotia, Canada (Communities)

Dr. Rayanna Hellem Santos Bezerra, Universidade Federal de Sergipe, São Cristóvão, Brazil

Dr. Jamie R. Wood, Landcare Research, Canterbury, New Zealand

Dr. Wendy Collinson-Jonker, Endangered Wildlife Trust, Gauteng, South Africa

Dr. Rajeshkumar G. Jani, Anand Agricultural University, Anand, Gujarat, India

Dr. O.N. Tiwari, Senior Scientist, ICAR-Indian Agricultural Research Institute (IARI), New

Delhi, India

Dr. L.D. Singla, Guru Angad Dev Veterinary and Animal Sciences University, Ludhiana, India

Dr. Rupika S. Rajakaruna, University of Peradeniya, Peradeniya, Sri Lanka

Dr. Bahar Baviskar, Wild-CER, Nagpur, Maharashtra 440013, India

Reviewers 2018-2020

Due to pausity of space, the list of reviewers for 2018-2020 is available online.
The opinions expressed by the authors do not reflect the views of the Journal of Threatened Taxa, Wildlife Information Liaison Development Society, Zoo Outreach Organization, or any of the partners. The journal, the publisher, the host, and the partners are not responsible for the accuracy of the political boundaries shown in the maps by the authors.

\footnotetext{
Print copies of the Journal are available at cost. Write to:

The Managing Editor, JoTT,

c/o Wildlife Information Liaison Development Society,

No. 12, Thiruvannamalai Nagar, Saravanampatti - Kalapatti Road,

Saravanampatti, Coimbatore, Tamil Nadu 641035, India

ravi@threatenedtaxa.org
} 


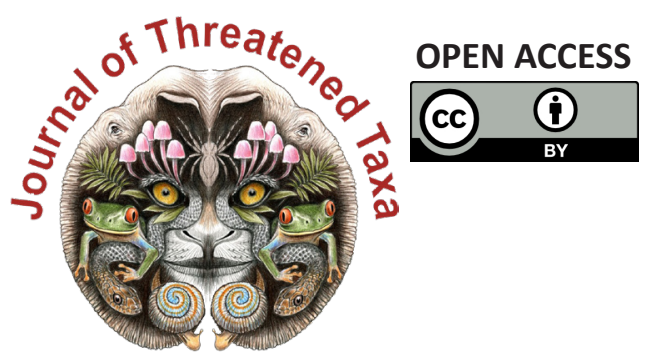

www.threatenedtaxa.org

The Journal of Threatened Taxa (JoTT) is dedicated to building evidence for conservation globally by publishing peer-reviewed articles online every month at a reasonably rapid rate at www.threatenedtaxa.org. All articles published in JoTT are registered under Creative Commons Attribution 4.0 International License unless otherwise mentioned. JoTT allows allows unrestricted use, reproduction, and distribution of articles in any medium by providing adequate credit to the author(s) and the source of publication.

\section{ISSN $0974-7907$ (Online) | ISSN $0974-7893$ (Print)}

\section{October 2021 | Vol. 13 | No. 12 | Pages: 19675-19886 \\ Date of Publication: 26 October 2021 (Online \& Print) DOI: 10.11609/jott.2021.13.12.19675-19886}

Articles

Roosting habits and habitats of the Indian Flying Fox Pteropus medius Temminck, 1825 in the northern districts of Tamil Nadu, India

- M. Pandian \& S. Suresh, Pp. 19675-19688

Diversity and distribution of avifauna at Warathenna-Hakkinda Environmental Protection Area in Kandy, Sri Lanka

- Dinelka Thilakarathne, Tithira Lakkana, Gayan Hirimuthugoda, Chaminda Wijesundara \& Shalika Kumburegama, Pp. 19689-19701

Grass species composition in tropical forest of southern India

- M. Ashokkumar, S. Swaminathan \& R. Nagarajan, Pp. 19702-19713

\section{Communications}

Habitat use and conservation threats to Wild Water Buffalo Bubalus arnee (Mammalia: Artiodactyla: Bovidae) in Koshi Tappu Wildlife Reserve, Nepal

- Reeta Khulal, Bijaya Neupane, Bijaya Dhami, Siddhartha Regmi, Ganesh Prasad Tiwari \& Manita Parajuli, Pp. 19714-19724

Get my head around owls: people perception and knowledge about owls of Andaman Islands

- Shanmugavel Sureshmarimuthu, Santhanakrishnan Babu, Nagaraj Rajeshkumar \& Honnavalli Nagaraj Kumara, Pp. 19725-19732

Abundance and diversity of threatened birds in Nangal Wetland, Punjab, India - Rajwinder Kaur \& Onkar Singh Brraich, Pp. 19733-19742

Evaluation of fish diversity and abundance in the Kabul River with comparisons between reaches above and below Kabul City, Afghanistan

- Ugyen Kelzang, Ahmad Farid Habibi \& Ryan J. Thoni, Pp. 19743-19752

New record of Myrmarachne melanocephala MacLeay, 1839 (Araneae: Salticidae) from Jharkhand, India and biogeographical implications of the co-occurrence of its ant model Tetraponera rufonigra Jerdon, 1851

- Rahul Kumar, Mirtunjay Sharma \& Ajay Kumar Sharma, Pp. 19753-19761

Diversity of spiders (Arachnida: Araneae) and the impact of pruning in Indian sandalwood plantations from Karnataka, India

-S. Padma 1 \& R. Sundararaj, Pp. 19762-19772

New records of cheilostome Bryozoa from the eastern coast of India encrusting on the exoskeleton of live horseshoe crabs of Indian Sundarbans

- Swati Das, Maria Susan Sanjay, Basudev Tripathy, C. Venkatraman \& K.A. Subramanian, Pp. 19773-19780

On the pteridophytes of Bherjan-Borajan-Padumoni Wildlife Sanctuary, Assam, India - Pranjal Borah \& Jayanta Barukial, Pp. 19781-19790

Population status of Heritiera fomes Buch.-Ham., a threatened species from Mahanadi Mangrove Wetland, India

- Sudam Charan Sahu, Manas Ranjan Mohanta \& N.H. Ravindranath, Pp. 19791-19798

Additions to the lichenized and lichenicolous fungi of Jammu \& Kashmir from Kishtwar High Altitude National Park

- Vishal Kumar, Yash Pal Sharma, Siljo Joseph, Roshinikumar Ngangom \& Sanjeeva Nayaka, Pp. 19799-19807

\section{Short Communications}

Is release of rehabilitated wildlife with embedded lead ammunition advisable? Plumbism in a Jaguar Panthera Onca (Mammalia: Carnivora: Felidae), survivor of gunshot wounds - Eduardo A. Díaz, Carolina Sáenz, E. Santiago Jiménez, David A. Egas \& Kelly Swing, Pp. 19808-19812

New record of the Sewing Needle Zipper Loach Paracanthocobitis linypha Singer \& Page, 2015 (Teleostei: Cypriniformes: Nemacheilidae) from the Chindwin drainage of Manipur, India

- Yumnam Rameshori, Yengkhom Chinglemba \& Waikhom Vishwanath, Pp. 19813-19817

Field identification characters to diagnose Microhyla mukhlesuri from closely related M. mymensinghensis (Amphibia: Microhylidae) and range extension of $M$. mukhlesuri up to West Bengal State, India

- Suman Pratihar \& Kaushik Deuti, Pp. 19818-19823
First report of Scipinia horrida (Stål) (Heteroptera: Reduviidae) from Assam, with comments on related genus Irantha Stål

- Anjana Singha Naorem, Santana Saikia, Anandita Buragohain, Rubina Azmeera Begum, Swapnil S. Boyane \& Hemant V. Ghate, Pp. 19824-19830

Flesh fly (Diptera: Sarcophagidae): male terminalia, diversity and expanded geographical distribution from India

- Kanholi Sreejith, Shuvra Kanti Sinha, Santanu Mahato \& Edamana Pushpalatha, Pp. 1983119836

Checklist of moths (Heterocera) of Tadong, Sikkim, India

- Prayash Chettri, Yuki Matsui, Hideshi Naka \& Archana Tiwari, Pp. 19837-19848

New distribution records of Begonia L., B. murina Craib and B. poilanei Kiew (Begoniaceae: Cucurbitales) for Laos

- Phongphayboun Phonepaseuth, Phetlasy Souladeth, Soulivanh Lanorsavanh, Shuichiro Tagane, Thyraphon Vongthavone \& Keooudone Souvannakhoummane Pp. 19849-19854

Notes

A recent sighting of the Stripe-backed Weasel Mustela strigidorsa (Mammalia: Carnivora: Mustelidae) in Hkakabo Razi Landscape, Myanmar

- Sai Sein Lin Oo, Tun Tun, Kyaw Myo Naing \& Paul Jeremy James Bates, Pp. 19855-19859

Are the uplifted reef beds in North Andaman letting nesting Olive Ridley Sea Turtle Lepidochelys olivacea stranded?

- Nehru Prabakaran, Anoop Raj Singh \& Vedagiri Thirumurugan, Pp. 19860-19863

First record of the orb-weaving spider Araneus tubabdominus Zhu \& Zhang, 1993 (Araneae: Araneidae) from India

- Souvik Sen, John T.D. Caleb \& Shelley Acharya, Pp. 19864-19866

The genus Catapiestus Perty, 1831 (Coleoptera: Tenebrionidae: Cnodalonini) from Arunachal Pradesh with one new record to India

- V.D. Hegde \& Sarita Yadav, Pp. 19867-19869

Rediscovery and extended distribution of Indigofera santapaui Sanjappa (Leguminosae: Papilionoideae) from the states of Maharashtra and Gujarat, India

- Kumar Vinod Chhotupuri Gosavi, Sanjay Gajanan Auti, Sharad Suresh Kambale \& Munivenkatappa Sanjappa, Pp. 19870-19873

Additional distribution records of Ceropegia anjanerica, an endemic and 'Endangered' lantern flower of the northern Western Ghats, India

- Samir Shrikant Maity, Ajay Natha Gangurde, Sharad Suresh Kambale, Avinash Ramchandra Gholave, Avinash Asraji Adsul, Ganesh Babaso Pawar \& Kumar Vinod Chhotupuri Gosavi, Pp. 19874-19877

Notes on the extended distribution of Impatiens megamalayana, a recently described balsam in Western Ghats, India

- Anoop P. Balan \& A.J. Robi, Pp. 19878-19883

Book Review

A look over on the scented tree of India (Santalum album - S. Suresh Ramanan \& A. Arunachalam, Pp. 19884-19886
Publisher \& Host
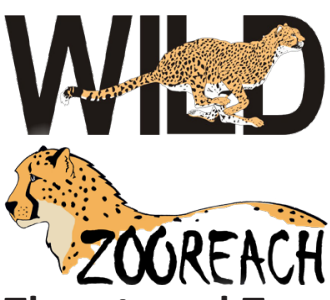

Threatened Taxa 